\title{
When skin showed a sign of pubertal growth:striae distensae of the lower back in a 12-year-old boy
}

\section{Rhizlane Chaoui, Selma El Kadiri, Sara Dahhouki, Zakia Douhi, Sara Elloudi, Hanane Baybay, Fatima Zahra Mernissi}

\author{
Department of Dermatology, University Hospital Hassan II, Fez, Morocco
}

Corresponding author: Dr. Rhizlane Chaoui, E-mail: chaoui.rhizlane@gmail.com

Sir,

A 12 year old boy, presented with asymptomatic erythematous marks on his lower back of six month's duration. He was otherwise healthy, no history of unmonitored exogenous steroid use or trauma or injury prior to onset of the lesions could be elicited.On the other hand, the mother noted a quite rapid growth spurt over the last years.

Dermatological examination revealed multiples horizontal striae distensae, erythematous in coulour, mesuring approximately $0.3 \mathrm{~cm}$ in width and $5 \mathrm{~cm}$ in length, involving the lower back (Fig. 1). There were no other marks elsewhere and the rest of the physical examination was normal.

On dermoscopy, we observed an erythema with telangiectasias (Fig. 2).

Blood tests including a full blood count, coagulation and routine biochemistry were normal.

The diagnosis of striae secondary to pubertal growth was made

The patient was prescribed topical tretinoin $0.05 \%$ cream once daily. Evolution is underway.

Striae distensae are linear atrophic plaques characterized by epidermal thinning that can cause significant psychological burden to the patient [1]. Its etiology still unknown but has been hypothesized that reduced levels of the genes encoding collagen and fibronectin are involved in the thinning of

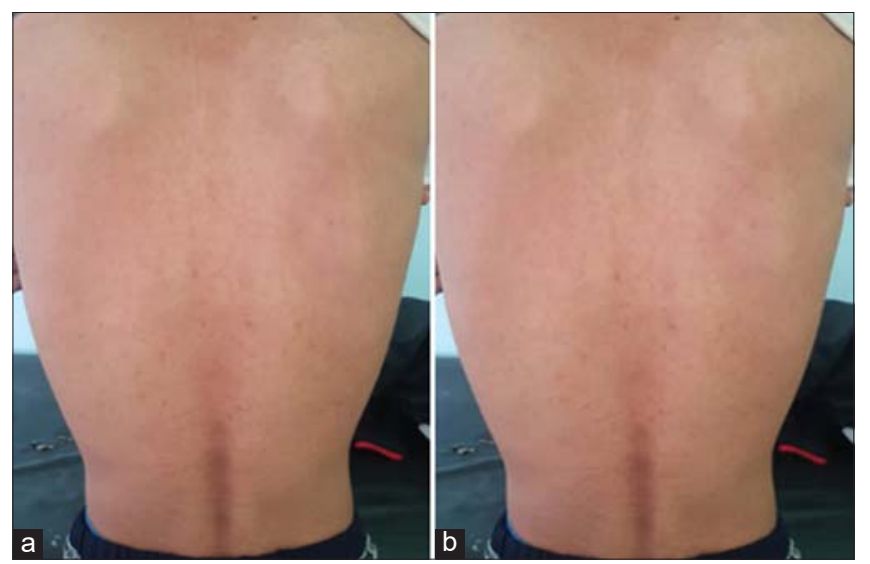

Figure 1: ( $a$ and $b$ ) Multiples linear red marks, mesuring approximately $0.3 \mathrm{~cm}$ in width and $5 \mathrm{~cm}$ in length, involving the lower back.

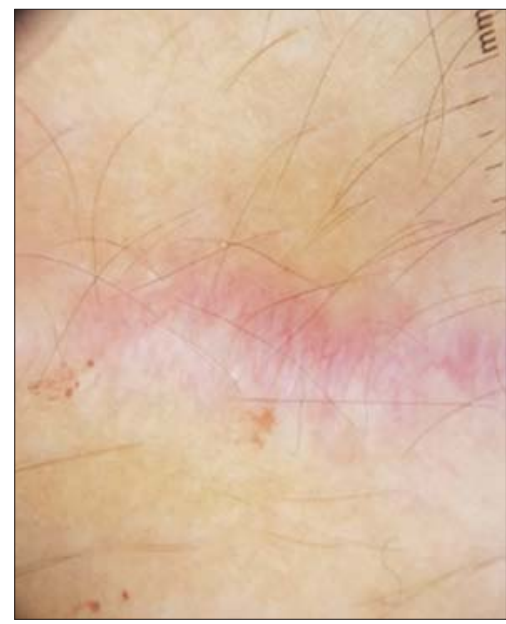

Figure 2: Dermoscopy showed erythema with telangiectasias.

connective tissue leading to the atrophic appearance of striae [2].

During adolescence, striae distensae is relatively common and is a physiological occurrence associated

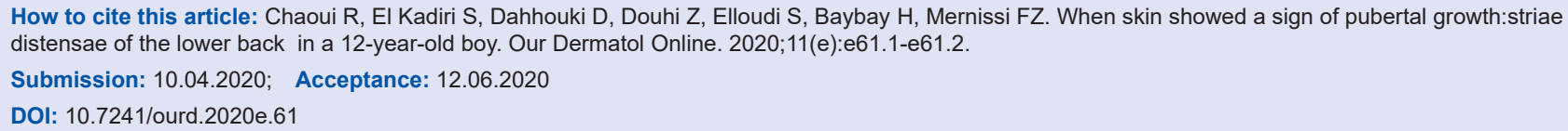


with sudden growth spurt [3]. The most commonly reported location for striae distensae was breasts, upper thighs, back and lower abdomen. Striae have also been observed in obese individuals and can be associated with Cushing syndrome, Marfan syndrome, other collagen disorders and with excessive marijuana use [3].

The case is being reported on account to thought about pubertal growth in case of striae distensae.

\section{Consent}

The examination of the patient was conducted according to the Declaration of Helsinki principles.

The authors certify that they have obtained all appropriate patient consent forms. In the form the patient(s) has/have given his/her/ their consent for his/her/their images and other clinical information to be reported in the journal. The patients understand that their names and initials will not be published and due efforts will be made to conceal their identity, but anonymity cannot be guaranteed.

\section{REFERENCES}

1. Boozalis E, Grossberg AL, Puttgen KB, Heath CR, Cohen BA. Demographic characteristics of teenage boys with horizontal striae distensae of the lower back. Ped Dermatol. 2018;35:59-63.

2. Malakar S, Diwaker P. Striae distensae over scalp: A trichoscopicr evelation. Our Dermatol Online. 2018;9:227-8.

3. Rafiei R, Hojat E, Daryakar A, Yusefkhani L, Rafiee B. Anetodermawith positive Darier'ssign. Our Dermatol Online. 2017;8:53-5.

Copyright by Rhizlane Chaoui, et al. This is an open access article distributed under the terms of the Creative Commons Attribution License, which permits unrestricted use, distribution, and reproduction in any medium, provided the original author and source are credited.

Source of Support: Nil, Conflict of Interest: None declared. 